\title{
EFFECT OF ACCELERATORS ON THE COMPRESSIVE STRENGTH DEVELOPMENT OF GEOPOLYMER CONCRETE COMPOSITES
}

\author{
Venkateswararao $\mathbf{J}^{1}$, Rambabu $\mathrm{K}^{2}$, Srinivasa Rao $\mathbf{K}^{3}$, Satish $\mathbf{N}^{4}$ \\ ${ }^{I}$ Department of Civil Engineering, GMR Institute of Technology, Rajam, A.P, India \\ ${ }^{2}$ Department of Civil Engineering, Andhra University, Visakhapatnam, A.P, India \\ ${ }^{3}$ Department of Civil Engineering, Andhra University, Visakhapatnam, A.P, India \\ ${ }^{4}$ Senior engineer $L \& T$ reality
}

\begin{abstract}
This study has examined the effect of three accelerators namely calcium chloride, sodium thiocyanate and potassium thiocyanate on the compressive strength development of geopolymer concrete composites. Geopolymer concrete composites were prepared by the geopolymerization of alkaline liquid with binder materials of $80 \%$ fly ash and $20 \%$ ground granulated blast furnace slag. Combination of sodium silicate and sodium hydroxide solutions was used as alkaline liquid in this investigation. A supplementary material zeolite also used to enhance the geopolymerization. The samples were cured at room temperature. Compressive strengths of geopolymer concrete composites at curing periods of 3, 7 and 28 days were determined. It was found that the addition of accelerators to geopolymer concrete composites results in significant improvement in the compressive strength at 3 and 7 days curing period while the compressive strength at 28 days was not affected.
\end{abstract}

Keywords: Geopolymer concrete composites, compressive strength, calcium chloride, sodium thiocyanate, potassium thiocyanate, GGBS, zeolite.

\section{INTRODUCTION}

Due to depletion of virgin materials with the increasing consumption, certainly prompting the construction industry to look for the sustainable resources (Mehta 2004). Cement, the principal binder in the production of concrete leading to emission of greenhouse gases. Approximately one tone of $\mathrm{CO}_{2}$ will be released in to atmosphere for every tonne Portland cement produced. More than $7 \%$ of world's $\mathrm{CO}_{2}$ production is attributed towards production of cement. The cement production is highly energy intensive next only to steel and aluminium and it consumes approximately about 1.5 tonnes of non-renewable natural resources such as lime stone deposits, coal, etc.(McCaffrey 2002). Concrete industry must play an active role in reducing the rate of greenhouse gas emissions, which is essential for the healthy and sustainable development. Use of other supplementary cementitious materials like fly ash, ground granulated blast furnace slag is the solution for reducing the cement clinker (Malhotra 2002). Recently, geopolymer materials, the supplementary materials to the ordinary Portland cement (OPC) have been of great interest to researchers as a new environmentally-friendly engineering technology due to their brilliant mechanical and thermal properties. Geopolymer technology can reduce $80-90 \%$ of $\mathrm{CO}_{2}$ emissions compared to the OPC (Davidovits 1999). Earlier investigations confirm the outstanding performance of geopolymer materials in terms of their early strength development, resistance to acid attacks, good freezingthawing cycles (Li et al. 2004, Gourley 2005 and Wallah et al. 2006).
However the use of heat medium for curing in the production of Geopolymer concrete is limiting its applications to the areas of precast products. Many researchers attempted in the past in producing geopolymer concrete under ambient curing condition by incorporating other industrial wastes such as Alkali Activated Slag. Several investigations were carried out on Alkali Activated slags (AAS) in reference to their mechanical properties (Glukhovsky et al. 1980, Wang et al. 1995, FernándezJiménez et al. 1999). Previous investigations reported better acid resistance of geopolymer concrete composites (Puetras 2002, Bakharev 2003). Excellent performance of slag cements at high temperature was reported in the recent times (Mejía et al. 2004). Potential engineering applications of granulated blast furnace slag-based geopolymers and their fabrication was already demonstrated by the researchers (Cheng et al. 2003). Previous investigations also revealed that under sufficient curing time AAS mortars cured at room temperature can attain equal or greater strengths than mortars cured at $80^{\circ} \mathrm{C}$ (Ekin et al 2012). Some researchers also used OPC to mobilize the setting and early strength properties of geopolymer concrete (Nath 2015). In the present experimental investigation fly ash was replaced with ground granulated blast furnace slag (GGBFS) and zeolite to eliminate the problem of heat curing. But it was found that the early day's compressive strength of geopolymer concrete composites was less compared to the heat curing geopolymer concrete. To address this problem various accelerators were added to the geopolymer concrete composites. The variation of compressive strength at 3, 7 and 28 days was reported when these accelerators were added to the geopolymer concrete composites. 


\section{MATERIALS AND METHODS}

Class F Fly ash and GGBFS are collected from locally available source NTPC Visakhapatnam, India and Toshali Cements Pvt. Ltd, Visakhapatnam, A.P, India, respectively. The physical properties of FA and GGBFS were given in Table 1. Zeolite material in the form of powder with 90micron size was used. The chemical composition of the materials as determined by X-ray fluorescence and is provided in Table 2. The alkaline activators used were laboratory-grade $>97 \%$ pure $\mathrm{NaOH}$ pellets and sodium silicate solution with specific gravity of 1.39 was used. The chemical composition of sodium silicate solution is: $\mathrm{Na}_{2} \mathrm{O}=$ $10.2 \%, \mathrm{SiO}_{2}=27.3 \%$ and water $62.5 \%$ by mass. Locally available sand and coarse aggregate are used. Specific gravity of fine and coarse aggregates was found to be in the range of 2.66 and 2.67 respectively. Tap water was used in preparing alkaline solution.

Table 1: Physical properties of Fly ash and GGBFS

\begin{tabular}{|l|l|l|}
\hline Physical Property & Fly ash & GGBFS \\
\hline Specific gravity & 2.05 & 2.9 \\
\hline Fineness $\left(\mathrm{m}^{2} / \mathrm{kg}\right)$ & 365 & 318 \\
\hline
\end{tabular}

Table 2: XRF analysis of Fly ash, GGBFS and Zeolite

\begin{tabular}{|l|l|l|l|}
\hline $\begin{array}{l}\text { Chemical } \\
\text { composition (\%) }\end{array}$ & Fly ash & GGBFS & Zeolite \\
\hline $\mathrm{Al}_{2} \mathrm{O}_{3}$ & 32.4 & 16.3 & 30.27 \\
\hline $\mathrm{Fe}_{2} \mathrm{O}_{3}$ & 4.04 & 0.68 & 2.54 \\
\hline $\mathrm{SiO}_{2}$ & 58.1 & 34.4 & 46 \\
\hline $\mathrm{CaO}$ & 1.4 & 34.6 & 0.3 \\
\hline $\mathrm{MgO}$ & 0.71 & 8.83 & - \\
\hline $\mathrm{SO}_{3}$ & 0.12 & 1.44 & 1.8 \\
\hline $\mathrm{Na}_{2} \mathrm{O}$ & 0.17 & 0.22 & 0.82 \\
\hline $\mathrm{Chlorides}$ & 0.02 & 0.01 & 0.4 \\
\hline
\end{tabular}

\subsection{Mixture Design and Specimen Preparation}

The alkali activator solution was prepared by mixing 16 molar $\mathrm{NaOH}$ with $\mathrm{Na}_{2} \mathrm{SiO}_{3}$ solution with $\mathrm{Na}_{2} \mathrm{SiO}_{3}$ to $\mathrm{NaOH}$ ratio of 2.5. The activator to binder ratio was kept at 0.6 for all the mixes. The mixture proportions of mixes are given in Table 3. Geopolymer concrete composites mix design procedure was according to the guide lines for GPC mix design reported by Anuradha et al. (2012). Fly ash/ground granulated blast furnace slag/zeolite in required proportions was thoroughly mixed in a mixer for about 2 minutes until uniform color is achieved. To this mix, fine and coarse aggregates were added and mixed again for about 3 minutes. At this stage an activator solution was then gradually added in to the mix for about 5 minutes simultaneously with water to improve the workability and homogeneity of the concrete. The concrete specimens were cast in $100 \mathrm{~mm}$ cube cast iron molds in three layers of equal height and compacted and were vibrated to remove entrained air and bubbles. After compaction, geopolymer concrete composites (GPCC), samples were cured at ambient laboratory conditions (25$30^{\circ} \mathrm{C}$ with a relative humidity of $70-80 \%$ ). The specimens were removed after 24 hours and kept undisturbed until testing day.
Table: 3: Mix proportions $\left(\mathrm{kg} / \mathrm{m}^{3}\right)$

\begin{tabular}{|l|l|}
\hline $\mathrm{Na}_{2} \mathrm{SiO}_{3}$ solution & 239.64 \\
\hline $\mathrm{NaOH}$ solution & 95.86 \\
\hline Extra water & 11 \\
\hline Fly ash & 550 \\
\hline Fine aggregate & 442 \\
\hline Coarse aggregate & 922 \\
\hline
\end{tabular}

\subsection{Test Procedures}

The workability of fresh geopolymer concrete mixes was determined using slump test as per IS: 1199 -1959. The compressive strength tests were performed in accordance with ASTM C109. The specimens were subjected to a compressive force at the rate of $5 \mathrm{kN} / \mathrm{s}$.

\section{RESULTS AND DISCUSSION}

Fresh and hardened properties of geopolymer concrete composites with various accelerators such as calcium chloride, sodium and potassium thiocyanate were determined and the results were discussed below.

\subsection{Influence of Accelerators on the Workability of Geopolymer Concrete Composites (GPCC)}

Figure 1 shows the variation in the workability of concrete before and after the addition of the accelerators to geopolymer concrete composite. Workability of the geopolymer concrete composite (GPCC) mix before adding accelerators was found to be greater than the workability of the GPCC after adding the accelerator. Addition of the accelerator calcium chloride $\left(\mathrm{CaCl}_{2}\right)$ caused drastic decrement in the slump. Addition of potassium thiocyanate caused $10 \mathrm{~mm}$ decrement in the slump. On the other hand addition of sodium thiocyanate caused $30 \mathrm{~mm}$ reduction in the slump of the mix. Figure 2 shows the variation in the workability of mixes for different percentages of ground granulated slag and zeolite. The maximum slump was obtained for GPCC -3 (FA - 70\% + GGBS - 20\% + Zeolite $10 \%)$.

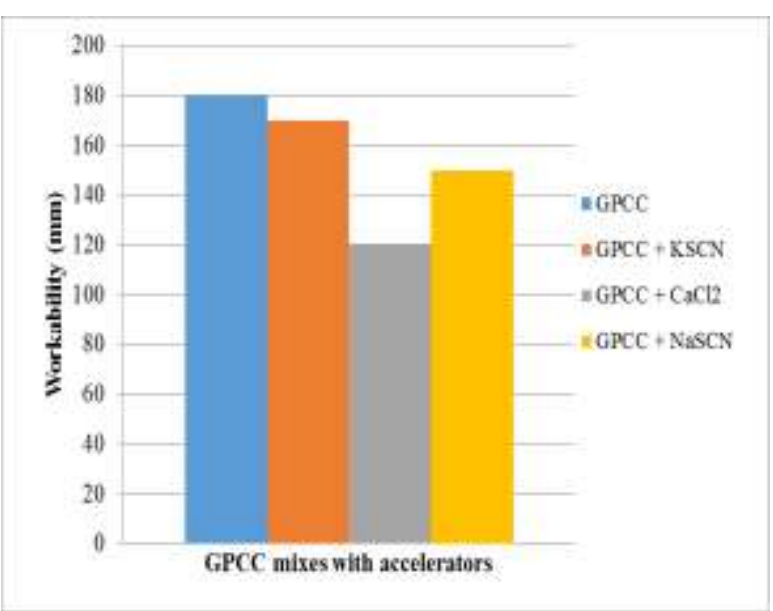

Fig 1: Variation of workability of geopolymer concrete composites with accelerators 
Minimum slump was obtained for GPCC -2 (FA - 70\% + GGBS - 10\% + Zeolite - 20\%). Mixes GPCC and GPCC -1 have intermediate values of slump. It can be inferred that with the increase in the GGBS slump was increasing.

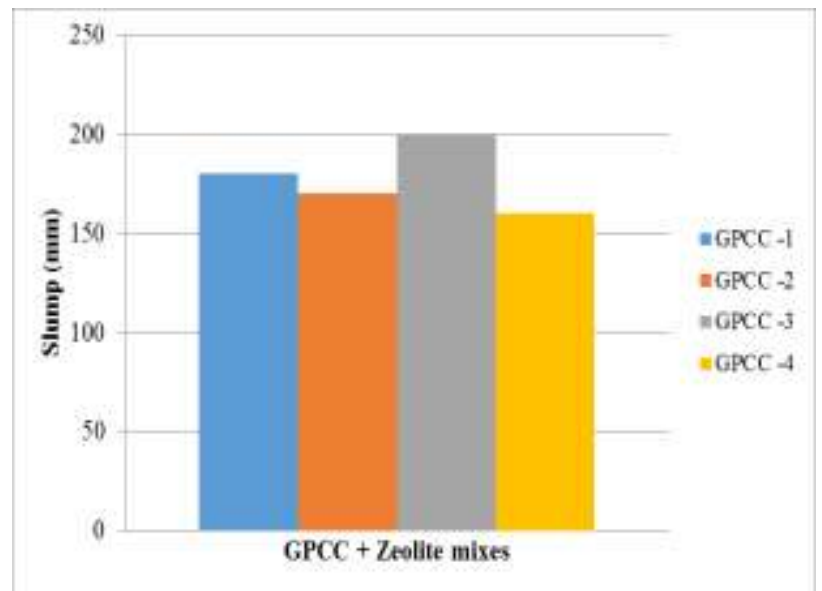

Fig 2: Variation of workability of geopolymer concrete composites mixes with zeolite

Figure 3 shows the workability of the mix GPCC -3 (FA $70 \%+$ GGBS $-20 \%+$ Zeolite $-10 \%$ ) after adding various accelerators. Addition of potassium thiocyanate caused decrement in the slump and results in early development of compressive strength.

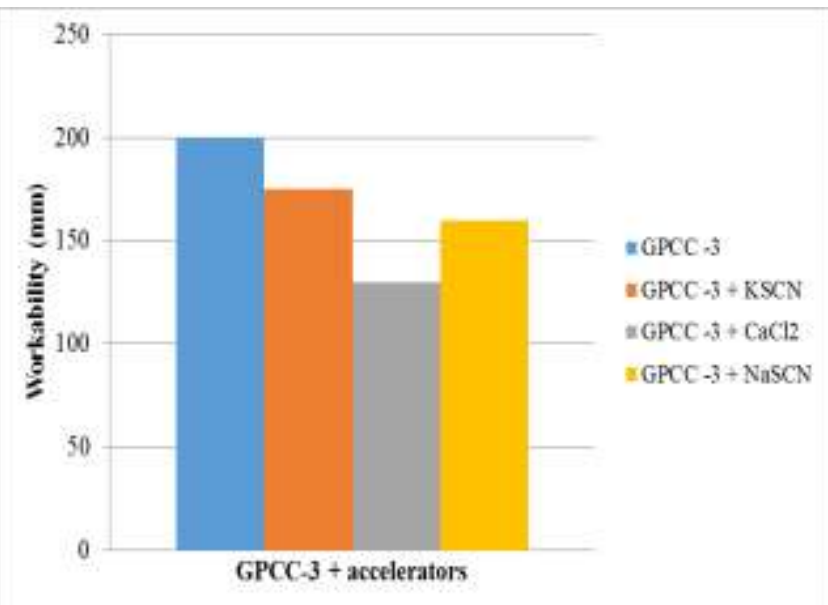

Fig 3: Variation in workability of GPCC -3 mixes with accelerators

Addition of calcium chloride caused sudden decrease in the slump but its 3 days average compressive strength was less than the mix with KSCN accelerator. The mix with sodium thiocyanate exhibited faster development of 3 days compressive strength.

\subsection{Influence of Accelerators on the Compressive}

\section{Strength Development of Geopolymer Concrete}

\section{Composites (GPCC)}

Development of average compressive strength of geopolymer concrete composites at the age of 3, 7 and 28 days curing period upon the addition of various accelerators were evaluated and the results were discussed below.

Figure 4 shows the influence of the accelerator, calcium chloride on the compressive strength development geopolymer concrete composites. The reference average compressive strength of geopolymer concrete composite (GPCC) at the age of 3 days was found to be $6.3 \mathrm{~N} / \mathrm{mm}^{2}$. Addition of $3 \%$ calcium chloride $\left(\mathrm{CaCl}_{2}\right)$ by weight of geopolymer binder results in an increase in the compressive strength by $46 \%$ to the reference compressive strength. Average 3 days compressive strength of GPCC after adding $3 \% \mathrm{CaCl}_{2}$ was about $25 \%$ of average 28 days compressive strength of GPCC without accelerator. Average compressive strength of geopolymer concrete composite at 7 days curing period after adding $3 \% \mathrm{CaCl}_{2}$ was found to be $26.9 \mathrm{~N} / \mathrm{mm}^{2}$. This shows an increment of $45 \%$ in the average compressive strength to the reference 7 days compressive strength of GPCC.

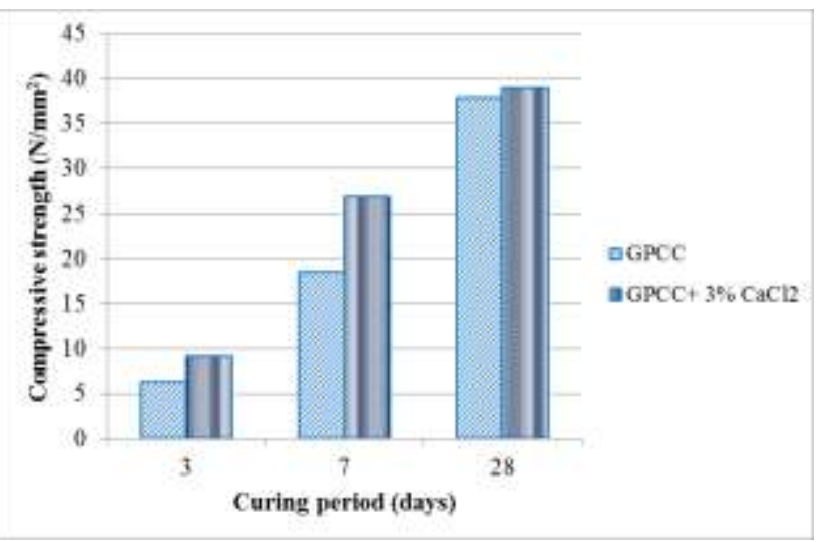

Fig 4: Influence of $\mathrm{CaCl}_{2}$ on the compressive strength development of GPCC

The average 7 days compressive strength was about $70 \%$ of the 28 days compressive strength of GPCC without the use of accelerator. At the age of 28 days, average compressive strength of geopolymer concrete composite was only marginally greater than that of the average compressive strength of reference geopolymer concrete composite at a curing period of 28 days. It can be concluded that addition of accelerator calcium chloride $\left(\mathrm{CaCl}_{2}\right)$ by $3 \%$ to the weight of binder accelerates the 3 and 7 days average compressive strength significantly, and does not show much influence on its compressive strength at 28 days of curing period.

Figure 5 shows the average 3, 7 and 28 days compressive strength development of geopolymer concrete composites with and without the addition of the accelerator sodium thiocyanate $(\mathrm{NaSCN})$. Sodium thiocyanate was added to the concrete mix by $3 \%$ to the weight of binder content. 


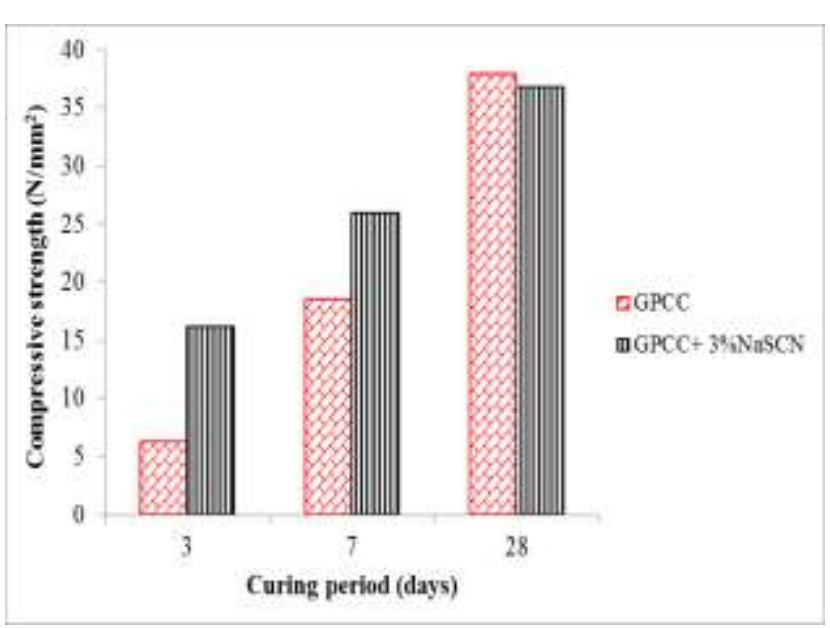

Fig Error! No text of specified style in document.: Influence of NASCN on the compressive strength de-velopment of GPCC

Average 3 days compressive strength of GPCC upon the addition of $\mathrm{NaSCN}$ was increased by $156 \%$ to the reference average compressive strength of GPCC at 3 days curing period. Average 3 days compressive strength of GPCC after adding $3 \% \mathrm{NaSCN}$ was found to be $16.1 \mathrm{~N} / \mathrm{mm}^{2}$, which was about $42 \%$ of average 28 days compressive strength of GPCC without accelerator.

Average 7 days compressive strength of geopolymer concrete composite after adding $3 \%$ sodium thiocyanate was found to be $26 \mathrm{~N} / \mathrm{mm}^{2}$. This shows an increment of $40 \%$ in the average compressive strength to the reference 7 days compressive strength of GPCC. The average 7 days compressive strength was about $69 \%$ of the 28 days compressive strength of GPCC without the use of accelerator. At the age of 28 days average compressive strength of geopolymer concrete composite was marginally decreasing compared to the average compressive strength of reference geopolymer concrete composite at a curing period of 28 days. It can be concluded that addition of accelerator sodium thiocyanate $(\mathrm{NaSCN})$ by $3 \%$ to the weight of binder accelerates the 3 and 7 days average compressive strength significantly, and while the average compressive strength of GPCC without accelerator at 28 days of curing period remains almost unaffected.

Figure 6 shows the influence of the accelerator, Potassium thiocyanate (KSCN) on the compressive strength development geopolymer concrete composites. Addition of $3 \%$ potassium thiocyanate by weight of geopolymer binder results in an increase in the compressive strength by $138 \%$ to the reference average compressive strength of GPCC at curing period of 3 days. Average 3 days compressive strength of GPCC after adding 3\% KSCN was found to be $15 \mathrm{~N} / \mathrm{mm}^{2}$, which was about $40 \%$ of average 28 days compressive strength of GPCC without accelerator. When the accelerator, potassium thiocyanate was increased in its dosage to $6 \%$ average 3 days compressive strength was reduced by $6 \%$ compared to $3 \%$ dosage. However average 3 days compressive strength was enhanced by $101 \%$ compared to reference average 3 days compressive strength of GPCC without accelerator.

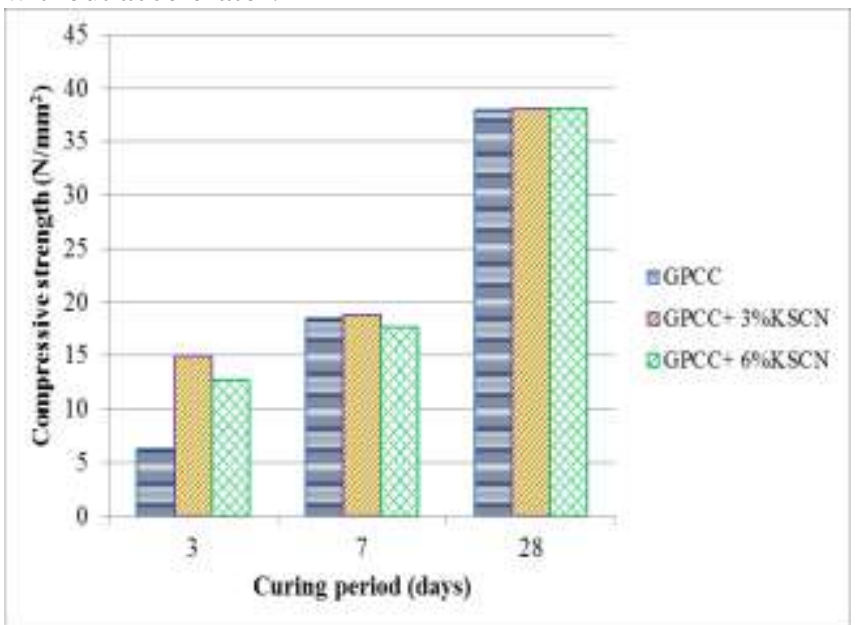

Fig 6 Influence of KSCN on the compressive strength develop -ment of GPCC

Average 7 days compressive strength of geopolymer concrete composite after adding $3 \%$ potassium thiocyanate was found to be $18.8 \mathrm{~N} / \mathrm{mm}^{2}$. This shows a marginal increment of $1.6 \%$ in the average compressive strength to the reference 7 days compressive strength of GPCC. The average 7 days compressive strength was about $50 \%$ of the 28 days compressive strength of GPCC without the use of accelerator.

Addition of $6 \% \mathrm{KSCN}$ results in decrease of average 7 days compressive strength compared to both GPCC without accelerator as well as GPCC with $3 \%$ accelerator dosage. Decrease in the average compressive strength was $6 \%$ with reference to the compressive strength of GPCC with $3 \%$ $\mathrm{KSCN}$ dosage. On the other hand the decrease in average 7 days compressive strength was about $5 \%$ with reference to the average 7 days compressive strength of GPCC without accelerator. At the age of 28 days average compressive strength of geopolymer concrete composite was comparable for all three mixes. Compressive strength of GPCC mixes with 3 and $6 \%$ dosages were same and these strengths slightly greater than the GPCC mix without accelerator at 28 days of curing period.

Figure 7 shows the influence of average 3, 7 and 28 days compressive strength developments of geopolymer concrete composites. Average 3 days compressive strength of geopolymer concrete composite (GPCC- $80 \%$ FA + 20\% GGBS) was found to be $6.3 \mathrm{~N} / \mathrm{mm}^{2}$, which was about $17 \%$ of its 28 days compressive strength. At the age of 3 days, GPCC -1 (80\% FA + 10\% GGBS + 10\% Zeolite) exhibited a compressive strength of $4.1 \mathrm{~N} / \mathrm{mm}^{2}$, which was $34 \%$ less compared to compressive strength of GPCC at 3 days curing period. Average 3 days compressive strength of GPCC -2 $\left(70 \% \mathrm{FA}+10 \% \mathrm{GGBS}+20 \%\right.$ Zeolite) was $3.7 \mathrm{~N} / \mathrm{mm}^{2}$, which was about $11 \%$ of its 28 days compressive strength. 
GPCC-2 has $41 \%$ less compressive strength than the average 3 days compressive strength of GPCC. GPCC -3 (70\% FA + $20 \%$ GGBS $+10 \%$ Zeolite) exhibited an average compressive strength of $12 \mathrm{~N} / \mathrm{mm}^{2}$, which was about $30 \%$ of its 28 days compressive strength. GPCC-3 possesses $90 \%$ greater average 3 days compressive strength than average 3 days compressive strength of GPCC. Average 7 days compressive strength of GPCC -2 was $12.4 \mathrm{~N} / \mathrm{mm}^{2}$, which was about $34 \%$ of its 28 days compressive strength. GPCC 1 and GPCC-2 possesses 33 and $48 \%$ less strength compared to average 7 days compressive strength of GPCC.

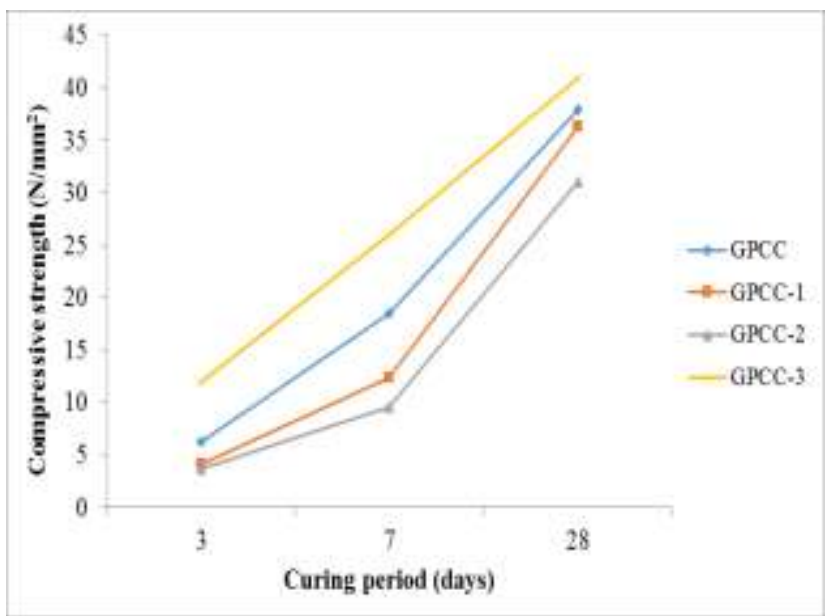

Fig 7 Influence of Zeolite on the compressive strength de velopment of GPCC

GPCC -3 developed $30 \%$ of its 28 days compressive strength at the age of 7 days curing period. GPCC -3 exhibited highest compressive strength at the age of 28 days. Average 28 days compressive strength of GPCC -3 was more than the average compressive strength of GPCC, GPCC-1, and GPCC- 2 by 8,12 and $31 \%$ respectively. Hence GPCC-3 (70\% FA + 20\% GGBS + 10\% Zeolite) exhibiting better performance in its compressive strength development at 3,7 and 28 days of curing period. Performance of GPCC -1 and GPCC -2 in terms of its compressive strength development was inferior to even the reference mix GPCC. Therefore addition $10 \%$ lime to the GPCC (80\% FA + 20\% GGBS) mix improves not only its early strength but also at later days of curing period.

Figure 8 shows the influence of various accelerators on the average compressive strength development of geopolymer concrete composites. As GPCC-3 performance was found to be best of all the combinations, in terms of its compressive strength development, to enhance its compressive strength accelerators were added. By adding 3\% calcium chloride $\left(\mathrm{CaCl}_{2}\right)$ to GPCC- 3, its average 3 days compressive strength was enhanced by $135 \%$ compared to the average 3 days compressive strength of GPCC. $\mathrm{CaCl}_{2}$ has accelerated the average 3 days compressive strength of GPCC -3 by $23 \%$.

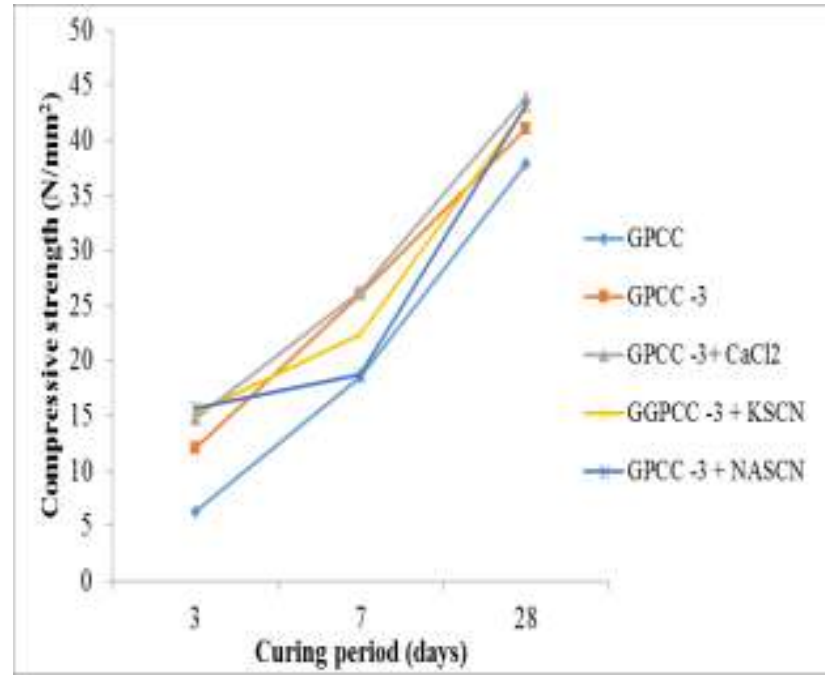

Fig 8 Influence of accelerators on the compressive strength development of GPCC -3

Addition of $3 \%$ potassium thiocyanate $(\mathrm{KSCN})$ resulted in an increment in the average 3 days compressive strength by $141 \%$ compared to the compressive strength of GPCC. Similarly when $3 \%$ sodium thiocyanate $(\mathrm{NaSCN})$ was added to GPCC -3 , there was increment in its compressive strength by $149 \%$ compared to GPCC. Addition of accelerators $\mathrm{CaCl}_{2}, \mathrm{KSCN}$, NASCN by $3 \%$ weight of binder resulted in an increase in the compressive strength of GPCC-3 mix by 23,27 and $31 \%$ respectively.

Addition of $3 \%$ calcium chloride results in an increment of 7 days compressive strength of GPCC-3 by $4.6 \%$. Compared to GPCC its strength was enhanced by $47 \%$. Average 7 days compressive strength of GPCC -3 was about $62 \%$ of its 28 days compressive strength. Average 7 days compressive strength of GPCC -3 was increased by $3 \%$ upon the addition of $3 \%$ potassium thiocyanate (KSCN). But it was $45 \%$ enhanced when compared to the average 7 days compressive strength of reference GPCC mix. Average 7 days compressive strength was about $63 \%$ of its 28 days compressive strength after the addition of $3 \% \mathrm{KSCN}$. Similarly addition of $3 \%$ sodium thiocyanate results in an increase in 7 days compressive strength of GPCC-3 mix by $3.8 \%$. But compared to 7 days compressive strength of GPCC mix it was enhanced by $46 \%$. Average 7 days compressive strength development of GPCC -3 after adding $3 \% \mathrm{NaSCN}$ was about $62 \%$ of its 28 days compressive strength. Average 28 days compressive strength of GPCC -3 was enhanced by $15 \%$ after adding $3 \%$ Calcium chloride accelerator. It was about $7 \%$ more than the average 28 days compressive strength of reference GPCC mix. Similarly there was an increment in the average 28 days compressive strength of GPCC -3 by 4.6 and $5.3 \%$ when $3 \% \mathrm{KSCN}$ and NaSCN were added to GPCC -3 . Average 28 days compressive strength of GPCC-3 after the addition of KSCN and $\mathrm{NaSCN}$ were about $13 \%$ greater than the average 28 days compressive strength of reference GPCC mix. 


\section{CONCLUSION}

1. Addition of $3 \%$ potassium thiocyanate to GPCC increased its 3 and 7 days compressive strength by 138 and $1.6 \%$ respectively while this addition has no effect on 28 days strength.

2. When $3 \%$ NASCN was added to GPCC, the increment in 3 and 7 days compressive strengths was found to be 156 and $40 \%$ respectively. In case of $\mathrm{CaCl}_{2}$ these increments were found to be $46 \%$ and $45 \%$ respectively.

3. Among the mixes of GPCC with various combinations of fly ash + GGBS + Zeolite, the best combination was found to be GPCC -3 (FA - 70\% + GGBS - 20\% + Zeolite $-10 \%)$ in terms of development of highest compressive strength. At 3,7 and 28 days, the compressive strengths of GPCC -3 mix were 90, 40, and $8 \%$ more compared to that of reference GPCC mix.

4. Use of $3 \%$ calcium chloride enhanced the compressive strength of GPCC -3 (FA - 70\% + GGBS - 20\% + Zeolite $-10 \%$ ) mix by $23,4.6$ and $7 \%$ at 3,7 and 28 days respectively.

5. When $3 \%$ potassium thiocyanate was added, the compressive strength of GPCC -3(FA - 70\% + GGBS $20 \%+$ Zeolite $-10 \%$ ) was enhanced by $27,3.1$ and $4.6 \%$ at 3,7 and 28 days of curing periods respectively. Increments in 3, 7 and 28 days compressive strengths of GPCC-3 were found to be $31,3.8$ and $5.3 \%$ respectively, when $3 \%$ sodium thiocyanate was used as accelerator.

\section{ACKNOWLEDGEMENTS}

Authors wish to gratefully acknowledge the services of their students Chandrasekhar. K., Shruthi. D., Anvesh. N. and Raghu Kiran.B.

\section{REFERENCES}

[1] Mehta P. K. (2004), 'High-performance, high-volume fly ash concrete for sustainable development', Proceedings of International Workshop on Sustainable Development and Concrete Technology, Beijing China. pp. 3-14.

[2] McCaffrey, R. (2002), 'Climate Change and the Cement Industry' Global Cement and Lime magazine (Environmental Special Issue), 15-19.

[3] V. Mohan Malhotra, Reducing $\mathrm{CO}_{2}$ Emissions: Concrete International, Vol. 28, Issue: 09, pp. 42-45, 2002.

[4] Davidovits J., Chemistry of Geopolymeric Systems, Terminology, In Proceedings of Second International Conference on Geopolymers, Saint-Quentin, France, pp. 9-40,28-29 June 1999.

[5] Wallah, S.E., Rangan, B.V., Low-Calcium Fly Ash Based Geopolymer Concrete: Long-Term Properties, In Research Report GC2; Faculty of Engineering, Curtin University of Technology, Perth, Australia, 2006.

[6] Li, Z.; Ding, Z., Zhang, Y. Development of Sustainable Cementitious Materials, In Proceedings of International Workshop on Sustainable
Development and Concrete Technology, Beijing, China, pp. 20-21,20-21 May 2004.

[7] Gourley J., Johnson, G. Developments in Geopolymer Precast Concrete, In Proceedings of Fourth World Congress Geopolymer, Saint- Quentin, France, pp. 133-1371, July 2005.

[8] Glukhovsky VD, Rostovskaja GS, Rumyna GV. High strength slag-alkaline cements, 7th international congress on the chemistry of cement. Paris: Editions Septima, pp. 164-168, 1980.

[9] Wang SD, Pu XC, Scrivener KL, Pratt PL. Alkaliactivated slag cement and concrete: a review of properties and problems. Advances in Cement Research; vol. 7, No. 27, pp. 93-102, 1995.

[10] Fernández-Jiménez A, Palomo JG, Puertas F. Alkaliactivated slag mortars: mechanical strength behavior, Cement Concrete Research; vol. 8, no.29, pp.131321, 1999.

[11] Puertas F, de Gutierrez R, Fernández-Jiménez A, Delvasto S, Maldonado Alkaline cement mortars. Chemical resistance to sulphate and seawater attack.Mater. Constr., vol.52, no.267, pp.55-71, 2002.

[12] Bakharev T, Sanjayan JG, Cheng Y-B. Resistance of alkali-activated slag concrete to acid attack. Cem. Concr Res; Vol.10, no.33, 1607-1611, 2003.

[13] Mejía de Gutierrez R, Maldonado J, Gutiérrez C. Performance of alkaline activated slag at high temperatures. Mater Constr., vol.54, no.276, 87-94, 2004.

[14] Daniel L.Y. Kong, Jay G. Sanjayan. Effect of elevated temperatures on geopolymer paste, mortar and concrete. Cem. Concr Res., vol. 40, pp. 334-339, 2010.

[15] Cheng T.W., Chiu J.P., Fire-resistant geopolymer produced by granulated blast furnace slag, Minerals Engineering, Vol 16, pp. 205-210, 2003.

[16] Ekin Altan, Sinan T. Erdogan. Alkali activation of a slag at ambient and elevated temperatures. Cem. Concr Res 2012; 34:131-139.

[17] Pradip Nath', Prabir Kumar Sarker., Use of OPC to improve setting and early strength properties of low calcium fly ash geopolymer concrete cured at room temperature, Cement\& Concrete Composites, Vol 55, pp. 205-214,2015. 